\title{
Financial Liquidity Variance Analysis of Select Steel Companies in India
}

\author{
M. Krishnamoorthi \\ Department of Management Studies, Priyadarshini Engineering College, Vaniyambadi, India
}

Email address:

mkrizhnaa@yahoo.co.in

\section{To cite this article:}

M. Krishnamoorthi. Financial Liquidity Variance Analysis of Select Steel Companies in India. International Journal of Economic Behavior and Organization. Vol. 4, No. 5, 2016, pp. 40-44. doi: 10.11648/j.ijebo.20160405.11

Received: September 8, 2016; Accepted: January 6, 2017; Published: February 1, 2017

\begin{abstract}
To fulfill of the daily needs of company, management should think seriously about Liquidity position. Working Capital help to which a business remains in working on its operation. Liquidity position remains important for any business. The role of working capital in business is similar to that the heart in the human body. Funds are the life blood of business operation. Liquidity are rotated to various business activities through proper working capital management and any difficulty in the smooth flow of funds which may causes serious problem in business operations. Financial liquidity variance analysis of select steel companies in India is analysed and it concludes that the financial liquidity management occupies an significant place in financial management. The companies belong to same industry maintain different position of financial liquidity level and they have never received so much attention as in recent years.
\end{abstract}

Keywords: Liquididty, Working Capital, Current Assets, Current Liability, Cash, Operation

\section{Introduction}

The Indian Iron and Steel industry contributes significantly to the overall growth and development of the economy. As per the estimation of the ministry of steel, the industry today directly contributes to $2 \%$ of India's GDP. To satisfy the daily needs of an industrial unit, management should think seriously about Working Capital. Working Capital is such of capital that with the help of which a business remains in working condition. It remains live for any business units, To fulfill of the daily needs of company, management should think seriously about Liquidity position. Working Capital help to which a business remains in working on its operation. Liquidity position remains important for any business. The role of working capital in business is similar to that the heart in the human body. Funds are the life blood of business operation. Liquidity are rotated to various business activities through proper working capital management and any difficulty in the smooth flow of funds which may causes serious problem in business operations. Financial liquidity variance analysis of select steel companies in India is analysed and it concludes that the financial liquidity management occupies a significant place in financial management.
Liquidity management is more essential for the all firm and all firm investment in such current assets. as cash, inventories and receivables be inclined to be higher than investment in fixed assets. It is more complicated for small and medium scale firms to increase enough long term capital for the current assets. Liquidity management has obtained important position. Funds may be mobilising from issue of shares, long term and short term borrowings. It ploughing back of the earning of business and may be used to pay for purchase of raw material wages and payment of various overheads, subject of consume of funds is that they are of recurring nature, hence efficient working capital/Liquidity management requires a proper balance of generation and circulation of these funds without scarcity of funds. It will eliminate obstruction in the smooth function of firm and conducting its business operation efficiently.

\subsection{Statement of the Problem}

Liquidity Management is concerned with the problems that arise while the finance manager attempts to manage the current assets and the current liabilities. Because of its importance in firm. Financial liquidity considered the life blood and controlling business operation, hence a firm requires both fixed and current assets management. The 
effective utilization of the fixed assets however depends upon the level of usage in the current assets. The present study makes attempt to evaluation of financial liquidity performance of select steel companies in India.

\subsection{Objectives of Study}

To evaluate the liquidity performance variance of select steel companies in India

\section{Review of Literature}

Abdul Raheman (2007) investigated that there is a strong negative relationship between the variables of the working capital and profitability of the firm. It means that the cash conversion cycle, increase will lead to decrease profitability of the firm, and manager can create a positive value for the shareholders by reducing the cash conversion cycle to a possible minimum level, and found that there is a significant negative relationship between liquidity and profitability [1].

Shin and Soenen (1998) studied about the short term and long term solvency position of the company will lead to company's profitability. Further the strength of working capital management also leads to participation of corporate profitability. They found that there is a strong negative relation between the cash conversion cycle and corporate profitability [2].

Samiloglu and Demirgunes (2008) examined the effect of working capital management on firm profitability about companies listed at the Istanbul Stock exchange (ISE). Using the multiple regression models, the study examined the effect of working capital on firm profitability for the period of 1998-2007. The findings of the study show that accounts receivables period, inventory period and leverage affect firm profitability negatively; while growth (in sales) affects firm profitability positively [3].

Sasikala (2012) investigated that there is no relationship between liquidity and profitability, risk and profitability and concluded that the excessive liquidity may lead to lower profitability. So, the negative association between liquidity and profitability must control with effective liquidity management [4].

Bhaskar Bagchi Jayanta Chakrabarti and Piyal Basu Roy (2012) investigated the effect of working capital management on firm's profitability as measured by return on total assets and return on investment using a sample of Indian FMCG companies found a strong negative relationship between the measures of working capital management with corporate profitability using fixed effect model. Hence, the findings of the study highlight the importance of proficient working capital management to ensure an improvement in firm's profitability and this aspect must form part of the company's strategic and operational thinking in order to operate effectively and efficiently in India's new challenging economic environment [5].

M. Krishnamoorthi (2012) Liquidity plays a vital role in survival of a business. Some describe it as solvency, but it would be better if the term 'solvency' is reserved for "ability to survive in the long run". He concluded that companies belong to the same industry followed a different debt equity position during the study period. [6]

\section{Research Design}

The research design describes the theoretical plan and structure of the study to find answers to the research problem. It constitutes the outline for data collection, sampling techniques and framework for analysis of data. The present study is both descriptive and analytical nature.

\subsection{Data Collection}

The present study purely based on the secondary data only. The related data, suchas profit and loss account statement, balance sheet and some important key ratios were collected from the published annual reports of selected steel companies in India. Other related information was collected from the Centre for Monitoring Indian Economy (CMIE) Reports, official website of selected steel companies, NSE, BSE, annual report of the ministry of steel, Institute of Financial Management and Research (IFMR), Libraries of various institutions, research publications and various academic research reports. Further the researcher referred various finance related textbooks and journals.

\subsection{Sampling}

In order to analyse the liquidity performance of steel companies, the details of 72 companies were collected. From this, the steel companies which satisfied the following criteria which have been shortlisted for further research:

The companies listed in NSE and BSE, Availability of data for the period of 10 years, the company should have at least three years of continues profit during the study period, the companies declared and paid dividend for a minimum of three years during the study period and the selected steel companies have been classified as large and mid cap companies based on market capitalisation.

The companies' stocks with market capitalisation of Rs. 10,000 crore or more are large cap companies are Tata Steel Limited, SAIL, JSW Steel Limited and Visa Steel Limited

The companies' stocks with market capitalisation between Rs. 2,000 crore to Rs.10,000 crore are mid cap companies are Bhushan Steel Limited, JSPL Kalyani Steels Limited

\subsection{Framework for Analysis}

The various statistical tools are used to analyse liquidity performance of the selected steel companies in India. The study of financial statement such as profit and loss accounts and balance sheets through, solvency ratios, constitutes in the framework of analysis. The frame work of analysis contains data analysis by using of SPSS package with applications of ratio analysis and statistical tools of ANOVA.

\subsection{Analysis of Variances (ANOVA)}

Anova is the best statistical tool, which is used to test 
whether the means of more than quantitative variables are equal. and testing the significance difference in the means of specified classification. For the purpose of analyzing the equality of means for different ratios of different companies 'ANOVA' test is used in the present study.

\section{Analysis and Interpretation}

Current Ratio- Large Cap Companies

For the purpose of analyzing the equality of means for different ratios 'ANOVA' test is used. The following hypotheses are framed and tested by using ' $\mathrm{F}$ ' test to test the validity of the hypothesis.

Based on the data, the researcher has formulated the following hypothesis:

$\mathrm{H}_{0}$ : There is no significant difference in the mean Current Ratio among the large cap companies.

Table 1. Inferential Statistics Current Ratio- Large Cap Companies.

\begin{tabular}{lllllll}
\hline & Mean & SD & SE & F & p & Decision \\
\hline TATA & $1.29^{\mathrm{a}}$ & 0.95 & 0.30 & & & \\
SAIL & $1.29^{\mathrm{a}}$ & 0.31 & 0.10 & & & \\
JSW & $0.66^{\mathrm{a}}$ & 0.13 & 0.04 & 1.78 & .169 & Accept $\mathrm{H}_{0}$ \\
VISA & $1.16^{\mathrm{a}}$ & 1.00 & 0.32 & & & \\
Overall & 1.10 & 0.73 & 0.12 & & & \\
\hline
\end{tabular}

** Significant at $1 \%$

From the above table, it is observed that the $p$ value (169) is greater than 0.01 , the null hypothesis is accepted at the $5 \%$ level of significance. i.e. There is no significant difference in the mean Current Ratio among the Large cap companies.

Current Ratio- Mid Cap Companies

$\mathrm{H}_{0}$ : There is no significant difference in the mean Current Ratio among the mid cap companies

Table 2. Inferential Statistics Current Ratio- Mid Cap Companies.

\begin{tabular}{lllllll}
\hline & Mean & SD & SE & F & p & Decision \\
\hline BHUSHAN & $0.86^{\mathrm{a}}$ & 0.19 & 0.06 & & & \\
JSPL & $0.86^{\mathrm{a}}$ & 0.20 & 0.06 & 5.48 & 0.010 & Accept $\mathrm{H}_{0}$ \\
KALYANI & $1.14^{\mathrm{b}}$ & 0.25 & 0.08 & & & \\
Total & 0.95 & 0.25 & 0.04 & & & \\
\hline
\end{tabular}

** Significant at $1 \%$

From the above table, it is observed that the $\mathrm{p}$ value $(0.010)$ is greater than 0.01 ; null hypothesis is accepted at the $5 \%$ level of significance. i.e. There is no significant difference in the mean Current Ratio among the mid cap companies

Debt Equity Ratio- Large Cap Companies

$\mathrm{H}_{0}$ : There is no significant difference in the mean Debt Equity Ratio among the large cap companies.

Table 3. Inferential Statistics Debt Equity Ratio- Large Cap Companies.

\begin{tabular}{lllllll}
\hline & Mean & SD & SE & F & p & Decision \\
\hline TATA & $0.67^{\mathrm{a}}$ & 0.33 & 0.10 & & & \\
SAIL & $0.52^{\mathrm{a}}$ & 0.44 & 0.14 & & & \\
JSW & $1.36^{\mathrm{a}}$ & 1.02 & 0.32 & 9.99 & $.000^{* *}$ & Reject $\mathrm{H}_{0}$ \\
VISA & $2.66^{\mathrm{b}}$ & 1.57 & 0.50 & & & \\
Overall & 1.30 & 1.27 & 0.20 & & & \\
\hline
\end{tabular}

$* *$ Significant at $1 \%$

From the above table, it is observed that the $p$ value $(.000)$ is less than 0.01 ; null hypothesis is rejected at the $1 \%$ level of significance. i.e. Debt Equity Ratio differs significantly between Large cap companies.

Debt Equity Ratio- Mid Cap Companies

$\mathrm{H}_{0}$ : There is no significant difference in the mean Debt Equity Ratio among the mid cap companies.

Table 4. Inferential Statistics Debt Equity Ratio-Mid Cap Companies.

\begin{tabular}{lllllll}
\hline & Mean & SD & SE & F & p & Decision \\
\hline BHUSHAN & $2.73^{\mathrm{a}}$ & 0.72 & 0.23 & & & \\
JSPL & $1.27^{\mathrm{a}}$ & 0.20 & 0.06 & 64.00 & $.000^{* *}$ & Reject $\mathrm{H}_{0}$ \\
KALYANI & $0.52^{\mathrm{b}}$ & 0.18 & 0.06 & & & \\
Total & 1.51 & 1.03 & 0.19 & & & \\
\hline
\end{tabular}

$* *$ Significant at $1 \%$

From the above table, it is observed that the $\mathrm{p}$ value $(.000)$ is less than 0.01 ; null hypothesis is rejected at the $1 \%$ level of significance. i.e. Debt Equity Ratio differssignificantly between Mid cap companies.

Quick Ratio- Large Cap Companies

$\mathrm{H}_{0}$ : There is no significant difference in the mean Quick Ratio among the large cap companies.

Table 5. Inferential Statistics Quick Ratio- Large Cap Companies.

\begin{tabular}{lllllll}
\hline & Mean & SD & SE & F & p & Decision \\
\hline TATA & 0.99 & 0.97 & 0.31 & & & \\
SAIL & 0.99 & 0.33 & 0.10 & & & \\
JSW & 0.50 & 0.18 & 0.06 & 1.72 & $0.181^{* *}$ & Accept $\mathrm{H}_{0}$ \\
VISA & 0.70 & 0.50 & 0.16 & & & \\
Overall & 0.80 & 0.59 & 0.09 & & & \\
\hline
\end{tabular}

$* *$ Significant at $1 \%$

From the above table, it is observed that the $p$ value $(0.181)$ is greater than 0.01 , the null hypothesis is accepted at the $5 \%$ level of significance. i.e. Quick Ratio do not differs significantly between large cap companies.

Quick Ratio- Mid Cap Companies

$\mathrm{H}_{0}$ : There is no significant difference in the meanQuick Ratio among the mid cap companies

Table 6. Inferential Statistics Quick Ratio- Mid Cap Companies.

\begin{tabular}{lllllll}
\hline & Mean & SD & SE & F & p & Decision \\
\hline BHUSHAN & $0.96^{\mathrm{a}}$ & 0.15 & 0.05 & & & \\
JSPL & $0.91^{\mathrm{a}}$ & 0.15 & 0.05 & 5.64 & $0.009 * *$ & Reject $\mathrm{H}_{0}$ \\
KALYANI & $1.12^{\mathrm{b}}$ & 0.14 & 0.04 & & & \\
Total & 0.99 & 0.17 & 0.03 & & & \\
\hline
\end{tabular}

$* *$ Significant at $1 \%$

From the above table, it is observed that the $\mathrm{p}$ value $(0.009)$ is less than 0.01 , the null hypothesis is rejected at the $1 \%$ level of significance. i.e. Quick Ratio differs significantly between Mid cap companies..

Interest Coverage Ratio- Large Cap Companies

$\mathrm{H}_{0}$ : There is no significant difference in the mean Interest Coverage Ratio among the large cap companies.

The following table shows the mean and standard 
deviation of Interest Coverage Ratio of large cap companies like TATA, SAIL, JSW and VISA and summarizes the output of analysis.

Table 7. Inferential Statistics Interest Coverage Ratio- Large Cap Companies.

\begin{tabular}{lllllll}
\hline & Mean & SD & SE & F & p & Decision \\
\hline TATA & $13.14^{\mathrm{a}, \mathrm{b}}$ & 10.28 & 3.25 & & & \\
SAIL & $21.13^{\mathrm{b}}$ & 14.92 & 4.72 & 5.96 & $0.002^{* *}$ & Reject $\mathrm{H}_{0}$ \\
JSW & $3.90^{\mathrm{a}}$ & 1.36 & 0.43 & & & \\
VISA & $5.83^{\mathrm{a}}$ & 9.07 & 2.87 & & & \\
Overall & 11.00 & 11.94 & 1.89 & & & \\
\hline
\end{tabular}

** Significant at $1 \%$

From the above table, it is observed that the $\mathrm{p}$ value (0.002) is less than 0.01 , null hypothesis is rejected at $1 \%$ level of significance. i.e. Interest Coverage Ratio differs significantly between Large cap companies

Interest Coverage Ratio- Mid Cap Companies.

$\mathrm{H}_{0}$ : There is no significant difference in the mean Interest Coverage Ratio among the mid cap companies.

Table 8. Inferential Statistics Interest Coverage Ratio- Mid Cap Companies.

\begin{tabular}{lllllll}
\hline & Mean & SD & SE & F & p & Decision \\
\hline BHUSHAN & 6.77 & 4.54 & 1.43 & & & \\
JSPL & 8.19 & 2.28 & 0.72 & 0.47 & 0.632 & Accept $\mathrm{H}_{0}$ \\
KALYANI & 6.24 & 6.31 & 2.00 & & & \\
Total & 7.07 & 4.59 & 0.84 & & & \\
\hline
\end{tabular}

** Significant at $1 \%$

From the above table, it is observed that the $\mathrm{p}$ value (0.632) is greater than 0.05 ; null hypothesis is accepted at $5 \%$ level of significance. i.e. Interest Coverage Ratio do not differs significantly between Mid cap companies.

Financial Charges Coverage Ratio - Large Cap Companies

$\mathrm{H}_{0}$ : There is no significant difference in the mean Financial Charges Coverage Ratio among the large cap companies.

Table 9. Inferential Statistics Financial Charges Coverage Ratio - Large Cap Companies.

\begin{tabular}{lllllll}
\hline & Mean & SD & SE & F & p & Decision \\
\hline TATA & $14.90^{\mathrm{a}, \mathrm{b}}$ & 11.68 & 3.69 & & & \\
SAIL & $23.41^{\mathrm{b}}$ & 15.50 & 4.90 & 6.53 & $0.001^{* *}$ & Reject $\mathrm{H}_{0}$ \\
JSW & $4.91^{\mathrm{a}}$ & 1.43 & 0.45 & & & \\
VISA & $5.37^{\mathrm{a}}$ & 9.81 & 3.10 & & & \\
Overall & 12.15 & 13.01 & 2.06 & & & \\
\hline
\end{tabular}

** Significant at $1 \%$

From the above table, it is observed that the $\mathrm{p}$ value $(0.312)$ is greater than 0.05 , null hypothesis is accepted at $5 \%$ level of significance. i.e. Financial Charges Coverage Ratio do not differs significantly between Mid cap companies.

Financial Charges Coverage Ratio- Mid Cap Companies

$\mathrm{H}_{0}$ : There is no significant difference in the mean Financial Charges Coverage Ratio among the mid cap companies.
Table 10. Inferential Statistics Financial Charges Coverage Ratio- Mid Cap Companies.

\begin{tabular}{lllllll}
\hline & Mean & SD & SE & F & p & Decision \\
\hline BHUSHAN & 5.78 & 2.25 & 0.71 & & & \\
JSPL & 8.90 & 2.30 & 0.73 & 1.22 & 0.312 & Accept $\mathrm{H}_{0}$ \\
KALYANI & 7.76 & 7.15 & 2.26 & & & \\
Total & 7.48 & 4.56 & 0.83 & & & \\
\hline
\end{tabular}

** Significant at $5 \%$

From the above table, it is observed that the $\mathrm{p}$ value (0.312) is greater than 0.05 , null hypothesis is accepted at $5 \%$ level of significance. i.e. Financial Charges Coverage Ratio do not differs significantly between Mid cap companies.

\section{Findings of the Study}

It is observed that the $p$ value (. 169) is greater than 0.01 , the null hypothesis is accepted at the $5 \%$ level of significance. i.e. There is no significant difference in the mean Current Ratio among the Large cap companies.

Found that the $p$ value $(0.009)$ is less than 0.01 , the null hypothesis is rejected at the $1 \%$ level of significance. i.e. Quick Ratio differs significantly between Mid cap companies.

It is observed that the $p$ value $(0.312)$ is greater than 0.05 , null hypothesis is accepted at 5\% level of significance. i.e. Financial Charges Coverage Ratio do not differs significantly between Mid cap companies.

Found that the $p$ value $(0.312)$ is greater than 0.05 , null hypothesis is accepted at 5\% level of significance. i.e. Financial Charges Coverage Ratio do not differs significantly between Mid cap companies.

\section{Conclusion}

The liquidity management entitle for careful cash flow handling based on sound operating efficiency at regular intervals, the Proper control of credit, collection period, proper handling of inventory and other current assets. It also influence for sensible handing of funds not engaged and proper use of banks advances to finance seasonal requirements of the business operations and expansion planning. The study of Liquidity management plays vital role in financial management. It has never established so much consideration as in recent years. Liquidity management is an integral part of overall financial management. The present study concludes that the financial liquidity management occupies a significant place in financial management. The companies belong to same industry maintain different position of financial liquidity level and they have never received so much attention as in recent years.

\section{References}

[1] Abdul Raheman. (2007). Working Capital Management \& Profitability - Case of Pakistan Firms. International Review of Business Research, 3 (2), 275-296. 
[2] Shin \& Soenen. (1998). Efficiency of Working Capital \& Corporate Profitability. Finance India. 8 (2), 37-45.

[3] Samiloglu, F. \& Demirgunes, K. (2008). The Effect of Working Capital Management on firm Profitability: Evidence from Turkey. The International Journal of Applied Economics \& Finance, 2 (1), 44-50.

[4] Sasikala, D. (2012). Dr. Reddy's Liquidity Management \& Trade off between Liquidity, Risk \& Profitability: An Empirical Study. Indian Journal of Finance, (2), 24-31.

[5] Bhaskar Bagchi, Jayanta Chakrabarti \& Piyal Basu Roy, (2012). Influence of Working Capital Management on Profitability: A Study on Indian FMCG Companies. International Journal of Business \& Management, 7 (22), 110.

[6] Krishnamoorthi. M, Ramesh. M (2012) "the solvency analysis of selected steel companies in india - an empirical study" asian journal of research in business economics \& management 2 (6), 161-179.

[7] Krishnamoorthi. M. Ramesh. M (2012) "long term solvency (leverage) analysis of selected steel companies in india - an empirical study" international journal of management research and review, 2 (4), pp 525-538.

[8] Krishnamoorthi. M (2016) "Forecast Of Liquidity Position Of
Select Steel Companies In India" International Journal of Arts, Science \& Commerce 7 (2) (2), pp 154-160.

[9] Krishnamoorthi. M (2016) "Impact Of Liquidity, Turnover And Profitability On Dividend Payment Of Select Steel Companies In India" Asian Journal of Research in Social Sciences and Humanities 6 (7) pp. 1176-1188.

[10] Krishnamoorthi. M. Ramesh. M (2015) “A Study On The Liquidity Growth Analysis Of Selected Steel Companies In India" international journal of management and technologies, special issue, pp 221-225.

[11] www.nseindia.com.

[12] www.bseindia.com.

[13] www.moneycontrol.com.

[14] www.tatasteel.com.

[15] www.sail.co.in.

[16] www.jsw.in.

[17] www.visasteel.com.

[18] www.bhushan-group.org.

[19] www.jindalsteelpower.com. 